\title{
EVALUATION OF THE EJACULATE MICROBIOTA BY REAL-TIME PCR AND CULTURE-BASED TECHNIQUE
}

Voroshilina ES ${ }^{1,2} \otimes$, Zornikov DL ${ }^{1}$, Panacheva EA ${ }^{1,2}$

${ }^{1}$ Ural State Medical University of the Ministry of health, Yekaterinburg, Russia

${ }^{2}$ Medical Center "Garmonia", Yekaterinburg, Russia

\begin{abstract}
Among other things male sterility can be caused by inflammatory diseases of the urogenital tract, often associated with opportunistic microorganisms. Thus, it is necessary to implement modern methods for the detection and identification of opportunistic microorganisms in the urogenital tract. The aim of the work was to conduct comparative analysis of the ejaculate microbiota from men of the reproductive age and studied using quantitative polymerase chain reaction (PCR) and culture method. 86 samples of ejaculate collected from men aged 18-57 years after observing sexual abstinence for 3-5 days were examined. With culture study in $50 \%$ of samples we observed growth of gram positive facultative anaerobic bacteria in the amount less than $10^{3} \mathrm{CFU} / \mathrm{ml}$; in $16.3 \%$ of samples — the growth of bacteria was not observed. With real-time PCR in each sample 8-15 groups of microorganisms were detected (including the prevailing groups) in the amount of $10^{2}-10^{6} \mathrm{GE} / \mathrm{ml}$. In all 86 samples obligate anaerobes that cannot not be cultured in vitro were detected. The predominant groups of microorganisms, as determined by real-time PCR, were detected by the culture metod only in $24.4 \%$ of cases.
\end{abstract}

Keywords: ejaculate microbiota, real-time PCR, culture-based technique

Acknowledgments: the authors would like to thank V. N. Khayutin, director of Garmonia Medical Center, for allowing to conduct the study in the clinic's laboratory department.

Author contribution: Voroshilina ES — organization of the study, conducting tests, data analysis, article authoring; Zornikov DL — data analysis, statistical processing, article authoring; Panacheva EA — literature review, clinical data collection, statistical analysis, article authoring.

Compliance with ethical standards: the study was approved by the Ethics Committee of Ural State Medical University, Federal State Budget Educational Institution of Higher Education under the Ministry of Health of the Russian Federation (Minutes № 4 of October 18, 2017). All patients signed the informed written consent to participation in the study.

$\triangle$ Correspondence should be addressed: Ekaterina S. Voroshilina

Furmanova 30, Yekaterinburg, 620142; voroshilina@gmail.com

Received: 11.02.2019 Accepted: 28.02.2019 Published online: 11.03.2019

DOI: 10.24075/brsmu.2019.009

\section{СРАВНИТЕЛЬНОЕ ИССЛЕДОВАНИЕ МИКРОБИОТЫ ЭЯКУЛЯТА МЕТОДОМ КОЛИЧЕСТВЕННОЙ ПЦР И КУЛЬТУРАЛЬНЫМ МЕТОДОМ}

\author{
Е. С. Ворошилина ${ }^{1,2}$, Д. Л. Зорников ${ }^{1}$ Е. А. Паначева ${ }^{1,2}$
}

${ }^{1}$ Уральский государственный медицинский университет, Екатеринбург, Россия

2 Медицинский центр «Гармония», Екатеринбург, Россия

\begin{abstract}
Одной из причин мужского бесплодия могут быть воспалительные заболевания урогенитального тракта, развитие которых в ряде случаев ассоциировано с условно-патогенными микроорганизмами (УПМ). В связи с этим актуальна проблема внедрения современных методов выявления и идентификации УПМ в урогенитальном тракте. Целью работы было провести сравнительный анализ результатов исследования микробиоты эякулята мужчин репродуктивного возраста с помощью количественной полимеразной цепной реакции (ПЦР) (тест Андрофлор) и культурального метода. Исследовали 86 образцов эякулята, собранных у мужчин в возрасте 18-57 лет после соблюдения полового воздержания в течение 3-5 суток. При культуральном исследовании в 50\% образцов наблюдали рост грамположительных факультативно анаэробных бактерий в количестве менее $10^{3}$ KOE/Mл; в 16,3\% образцов - роста бактерий отмечено не было. При использовании ПЦР в реальном времени (ПЦР-РВ) в каждом образце выявляли 8-15 групп микроорганизмов (в том числе определяли преобладающую) в количестве 10²-106 ГЭ/мл. Во всех 86 образцах были обнаружены облигатные анаэробы, которые не культивируются in vitro. Преобладающие группы микроорганизмов, определяемые в ПцР-РВ, были выявлены культуральным методом только в $24,4 \%$ случаев.
\end{abstract}

Ключевые слова: микробиота эякулята, ПЦР-РВ, культуральный метод

Благодарности: авторы благодарят директора Медицинского центра «Гармония» В. Н. Хаютина за предоставленную возможность проведения исследования на базе лабораторного отделения клиники.

Информация о вкладе авторов: Е. С. Ворошилина - организация исследования, выполнение ПцР-РВ, анализ данных, написание статьи; Д. Л. Зорников - анализ данных, статистическая обработка, написание статьи; Е. А. Паначева - обзор литературы, сбор клинических данных, статистический анализ, написание статьи.

Соблюдение этических стандартов: исследование одобрено этическим комитетом при ФГБОУ ВО УГМУ МЗ РФ (протокол № 4 от 18 октября 2017 г.). Все пациенты подписали информированное письменное согласие на участие в исследовании.

$\triangle$ Для корреспонденции: Екатерина Сергеевна Ворошилина

ул. Фурманова, 30, г. Екатеринбург, 620142; voroshilina@gmail.com

Статья получена: 11.02.2019 Статья принята к печати: 28.02.2019 Опубликована онлайн: 11.03.2019

DOI: $10.24075 /$ vrgmu.2019.009

The idea of the sterility of some biotopes, urine and bladder in particular, has changed in a decade due to new data about human microbiome composition. Urine of healthy men contains a number of opportunistic microorganisms (OM) of genus Lactobacillus, Sneathia, Veillonella, Corynebacterium, Prevotella, Streptococcus and Ureaplasma [1]. Earlier, it was shown that bacteria inhabit only the urethra and coronal sulcus of the healthy men's urogenital tract (UGT) [2, 3, 4]. Later, bacteria were found in the upper sections of the UGT of clinically healthy men, prostate tissue in particular [5].

Semen microbiota originates from different parts of the UGT, and it is dominated with urethral bacteria in healthy men. In patients with symptoms of urogenital inflammation bacteria from the upper parts of the UGT could be detected in semen [2]. 
Composition of semen microbiota in patients withinfertility and prostatitis is of great interest for practical medicine. Recently, a number of differences were discovered between the composition of semen microbiota of healthy men and those suffering from prostatitis: the former had more Lactobacillus iners therein, while the semen of the latter generally had a greater number and diversity of microorganisms, including Proteobacteria phylum [6].

Male UGT infections are the cause of male infertility in $6-10 \%$ of cases [7]. However, etiology of prostatitis remains unclear; moreover, an appropriate treatment could not be prescribed to symptomatic patients with negative semen cultures [8]. Contribution of specific OM to the development of the UGT inflammatory processes is debatable. In the absence of obligate pathogens, opportunistic bacteria, like Escherichia coli, Klebsiella spp., Proteus spp., Enterococcus spp., Staphylococcus spp., Ureaplasma spp., Mycoplasma hominis etc. could trigger an inflammation [7]

Asymptomatic and subclinical forms of male urogenital infections have been frequently detected in the last decades. Evaluation of local inflammatory response and of the UGT microbiota composition helps us to establish a diagnosis in these cases. The use of highly informative laboratory tests is of great significance in the UGT's microbiota studies.

A number of methods are used for the semen microbiota composition evaluation. The real-time PCR (Androflor test) was introduced recently along with the traditional culture-based techniques. This method allows identifying all participants of complex microbial communities, including non-culturable microorganisms. Given the limited number of valid comparative studies, RT PCR could not be widely recommended instead of culture-based techniques.

This study aimed to compare semen microbiota composition analyzed by means of culture-based technique and the RT PCR (Androflor test).

\section{METHODS}

From January to May 2018, 86 semen samples were obtained from men who attended "Garmonia" Medical Center (Yekaterinburg) for resolving their reproduction problems. The patients were aged 18 to 57 years; mean age $34 \pm 6.7$ years. The inclusion criteria were: $3-5$ days of sexual abstinence before performing the test in order to prevent semen contamination with female transient microflora (Lactobacillus spp.). The exclusion criteria were: detection of obligate pathogens (Chlamydia trachomatis, Neisseria gonorrhoeae, Mycoplasma genitalium, Trichomonas vaginalis). Prior to semen collection the patients urinated, completely emptying their bladders. The semen was collected into a $60 \mathrm{ml}$ sterile container through masturbation; the patients were instructed not to touch the container's walls and lid with their hands. The samples were brought to the laboratory in a thermal container within 4 hours from collection. The semen culture and RT PCR were performed simultaneously from a given sample.

Semen cultures were performed at the Microbiological laboratory "Quality Med" (Yekaterinburg). One ml of semen was diluted with sterile saline $(1: 1)$ and centrifuged at $1500 \mathrm{rpm}$ for 15 minutes. After removal of the supernatant, $10 \mu \mathrm{l}$ of the sediment were plated on 5 nutrient media (Bio-Rad; France): $5 \%$ blood agar with whey and yeast extract; chocolate agar based on blood agar; UriSelect4 chromogenic agar; Saburo agar; Mannitol salt agar. The samples were incubated at $37^{\circ} \mathrm{C}$ for 24-48 $\mathrm{h}$ in aerobic conditions and in the 5\% $\mathrm{CO}_{2}$ atmosphere. The resulting colonies were identified with the matrix-assisted laser desorption/ionization time-of-flight mass spectrometry (MALDI-TOF MS) in a Vitek MS analyzer (BioMerieux; France).

PCR tests were performed at the laboratory of the "Garmonia" Medical Center (Yekaterinburg). One $\mathrm{ml}$ of semen was put into an Eppendorf tube with $1 \mathrm{ml}$ of transport medium with mucolytic (InterLabService; Russia), which was then shaken in the Fugue/ Vortex Micro-Spin FV-2400 centrifuge (BioSan; Latvia) until the substances mixed completely. The tube was centrifuged at $13,000 \mathrm{rpm}$ for 10 minutes. After removing the supernatant, $50 \mu \mathrm{l}$ of the precipitate was used for extraction of the DNA, using the PROBA-GS reagent kit (DNA-Technology; Russia) following the manufacturer's instructions. RT PCR was performed using the Androflor kit (DNA-Technology; Russia) and the DT-96 detection amplifier following the manufacturer's instructions (DNA-Technology; Russia) [9]. Once the amplification reaction was over, the special software (DNA-Technology; Russia) was used to automatically calculate the total bacterial load (TBL) and the proportion of particular species and groups of bacteria in relation to the TBL in the given sample. The quantity of identified microorganisms was expressed in genome equivalents per $1 \mathrm{ml}(\mathrm{GE} / \mathrm{ml})$. The kit allows identifying the following groups of OM: Gram-positive facultative anaerobes (Streptococcus spp. Staphylococcus spp., Corynebacterium spp.); Gram-negative facultative anaerobes (Haemophilus spp., Pseudomonas aeruginosa / Ralstonia spp. / Burkholderia spp.); Enterobacteriaceae / Enterococcus spp. group; obligate anaerobes (Gardnerella vaginalis, Eubacterium spp., Sneathia spp. I Leptotrichia spp./ Fusobacterium spp., Megasphaera spp./ Veillonella spp./ Dialister spp., Bacteroides spp./ Porphyromonas spp. /Prevotella spp., Anaerococcus spp., Peptostreptococcus spp., Atopobium cluster), mycoplasmas (Mycoplasma hominis, Ureaplasma urealyticum, Ureaplasma parvum), transient microbiota (Lactobacillus spp.), yeast-like fungi (Candida spp.).

Microsoft Excel 2016 (Microsoft; USA) and WinPepi statistical software were used to process the data obtained. Differences in prevalence of microbiota types detected by culture technique and RT PCR were evaluated using Fisher's test; the statistical significance was set at $p<0.05$ for correction of multiple comparisons.

\section{RESULTS}

\section{Semen culture results}

Semen cultures were positive in 72 (83.7\%) cases and 28 bacterial species were identified. Fourteen (16.3\%) samples were culture negative.

The growth of a single bacterial culture was established in $33(38.4 \%)$ samples. 10 bacterial species, mostly commensals, were identified. 21 (63.6\%) of the 33 samples contained one of the Gram-positive facultative anaerobes: Staphylococcus spp. (S. epidermidis, S. haemolyticus, S. hominis); Streptococcus spp. (S. anginosus), Corynebacterium coyleae, Dermabacter hominis. In $8(24.2 \%)$ cases Enterococcus faecalis was found, in $4(12.2 \%)$ samples out of 33 - Gram-negative facultative anaerobes Klebsiella oxytoca, E.coli, Moraxella osloensis were detected.

The majority of the samples (28 out of 33 , or $84.8 \%$ ) have the colony count of less than $10^{2}-10^{3} \mathrm{CFU} / \mathrm{m}$, which is considered clinically insignificant. $6(18.2 \%)$ samples have the colony count of $10^{4} \mathrm{CFU} / \mathrm{ml}$, and only in one sample the colony count was $10^{6} \mathrm{CFU} / \mathrm{ml}$.

Two bacterial cultures were detected in 27 (31.4\%) out of 86 samples, 20 bacterial species were identified. Gram-positive facultative anaerobes were identified in 16 (59.3\%) samples out 
of 27. The most typical combinations were $S$. mitis / S. oralis (8 cases); C. glucuronolyticum / S. epidermidis and E. faecalis / S.epidermidis (2 cases each); E. faecalis / S. haemolyticus, S. capitis / S. haemolyticus, S. epidermidis / S. agalactiae, C. glucuronolyticum / E. faecalis (1 case each). Gramnegative facultative anaerobes (Enterobacter hormaechei/ Pseudomonas aeruginosa) were established in one sample only. The combination of Gram-negative and Gram-positive facultative anaerobes was established in 5 (18.5\%) samples. The most typical combinations were: E. faecalis / E. coli (2 cases); Klebsiella pneumoniae / S. haemolyticus (2 cases) and $E$. Faecalis / K. oxytoca (1 case). G. vaginalis was identified in 2 samples (7.4\%), accompanied by Actinomyces neuii in one specimen and S. epidermidis in the other. Another 2 (7.4\%) samples contained Lactobacillus spp in combination with Grampositive cocci: L. iners / S. gallolyticus, L. crispatis / S. warneri.

The majority of samples (17 of 27 them, $62.9 \%$ ) have the colony count of less than $10^{2}-10^{3} \mathrm{CFU} / \mathrm{m}$ ), which is considered clinically insignificant [10]. The colony count of $10^{4} \mathrm{CFU} / \mathrm{ml}$ of at least one bacterial species (E. faecalis, K. oxytoca, G. vaginalis, S. agalactiae) was established in 9 (33.3\%) specimens. The colony count of both isolated species (K. pneumoniae / S. haemolyticus) reached $10^{6} \mathrm{CFU} / \mathrm{ml}$ just in one specimen.

Three bacterial cultures were detected in 9 samples (10.5\%), 12 species were identified in various combinations. The mixed microbiota with Gram-positive facultative anaerobes was established in 4 (44.4\%) out of 9 specimens: C. glucuronolyticum, S. mitis / S. oralis, S. hominis. Combinations of C. glucuronolyticum / G. vaginalis / S. anginosus were detected in 2 (22.2\%) samples. The combinations of Gram-positive and Gram-negative facultative anaerobes were established in 3 cases: S. agalactiae / E. coli / C. glucuronolyticum; Corynebacterium amycolatum / E. hormaechei / E. Faecalis and E. faecalis / E. coli / S. anginosus.

The colony count was clinically insignificant (less than $10^{3}$ $\mathrm{CFU} / \mathrm{ml}$ ) in 3 out of 9 samples. In 6 other specimens the colony count of at least one species was $10^{4} \mathrm{CFU} / \mathrm{ml}$ or more withthe prevalenceof C. glucuronolyticum, E. hormaechei, E. faecalis, S. anginosus, G. vaginalis or $S$. agalactiae.
Four and more bacterial cultures were detected in just 3 samples. The combination of C. gluconormum / E. faecalis / S. mitis / S. oralis / E. coli, with E. faecalisin $10^{4} \mathrm{CFU} / \mathrm{ml}$, was determined in one specimen. In two other cases the combinations of commensal Gram-positive bacteria with colony count less than $10^{3} \mathrm{CFU} / \mathrm{ml}$ suggested potential contamination with skin microflora during semen collection.

\section{Semen RT PCR results}

RT PCR identified microflora in all 86 semen specimens: from 8 to 15 groups of bacteria were detected in each, the amounts ranging from $10^{2}$ to $10^{6} \mathrm{GE} / \mathrm{ml}$. A mathematical algorithm was applied to calculate the proportion of each group of microorganisms in the TBL; the predominant group of bacteria (the proportion of which in the TML exceeds that of other bacteria detected) was determined in the most samples.

Gram-positive facultative anaerobes - the UGT microbiota's Streptococcus spp., Staphyloccus spp., and Corynebacterium spp. - were abundant in 15 (17.4\%) samples. Obligate anaerobes prevailed in 27 (31.4\%) samples, Gram-negative facultative anaerobes (P. aeruginosa / Ralstonia spp./ Burkholderia spp. and Haemophilus spp.) - in 4 (4.7\%) samples. Enterobacteriaceae / Enterococcus spp. group was abundant in 23 (26.7\%) samples; transient microbiota (Lactobacillus spp.) — in 7 (8.1\%) samples. Polymicrobial communities without a predominant group were identified in $10(11.6 \%)$ samples. The latter demonstrates that RT PCR detected heterogeneous semen microbiota, culture technique failed to find.

When analysing the semen microbiota RT PCR results, we considered the fact that the microorganisms detected in semen could not be regarded as a microbial community or a microbiocenosis because they come from different parts of the man's UGT. Therefore, we suggest classifying the semen microbiota according to the predominant group of microorganisms. This criterion allowed discriminating 6 types of the semen microbiota; their detection rate was analyzed taking into account the TBL (Table 1).

Table 1. Semen microbiota variants, RT PCR data $(n=86)$

\begin{tabular}{|c|c|c|c|c|c|}
\hline $\begin{array}{l}\text { Semen } \\
\text { microbiota type }\end{array}$ & $\begin{array}{l}\text { Predominant group of microorganisms } \\
\text { in the semen microflora }\end{array}$ & $\begin{array}{c}\mathrm{TBM}<10^{3} \mathrm{GE} / \mathrm{ml} \\
n(\%)\end{array}$ & $\begin{array}{c}\text { TBM } 10^{3}<10^{4} \mathrm{GE} / \mathrm{ml} \\
n(\%)\end{array}$ & $\begin{array}{c}\mathrm{TBM}>10^{4} \mathrm{GE} / \mathrm{ml} \\
n(\%)\end{array}$ & $\begin{array}{l}\text { Significance of } \\
\text { differences }^{3}\end{array}$ \\
\hline & & 1 & 2 & 3 & \\
\hline Microbiota type I & $\begin{array}{l}\text { Gram-positive facultative } \\
\text { anaerobes }\end{array}$ & $4(14.8)$ & $9(19.6)$ & $2(15.4)$ & $\begin{array}{l}p_{1-2}>0.05 \\
p_{1-3}>0.05 \\
p_{2-3}>0.05\end{array}$ \\
\hline Microbiota type II & $\begin{array}{l}\text { Gram-negative facultative } \\
\text { anaerobes }\end{array}$ & $2(7.4)$ & $2(4.4)$ & 0 & $\begin{array}{l}p_{1-2}>0.05 \\
p_{1-3}>0.05 \\
p_{2-3}>0.05\end{array}$ \\
\hline Microbiota type III & $\begin{array}{c}\text { Enterobacteriaceae spp./Enterococcus spp. } \\
\text { group }^{1}\end{array}$ & $12(44.4)$ & $8(17.4)$ & $3(23.1)$ & $\begin{array}{l}p_{1-2}<0.05 \\
p_{1-3}<0.05 \\
p_{2-3}>0.05\end{array}$ \\
\hline Microbiota type IV & Obligate anaerobes & $2(7.4)$ & $19(41.3)$ & $6(46.2)$ & $\begin{array}{l}p_{1-2}<0.01 \\
p_{1-3}<0.01 \\
p_{2-3}>0.05\end{array}$ \\
\hline Microbiota type V & $\begin{array}{l}\text { Transient microflora } \\
\text { (Lactobacillus spp.) }\end{array}$ & $1(3.7 \%)$ & $4(8.7)$ & $2(15.4)$ & $\begin{array}{l}p_{1-2}>0.05 \\
p_{1-3}>0.05 \\
p_{2-3}>0.05\end{array}$ \\
\hline Microbiota type VI & $\begin{array}{l}\text { No predominant group } \\
\text { (polymicrobial community) }\end{array}$ & $6(22.2 \%)$ & $4(8.7)$ & 0 & $\begin{array}{l}p_{1-2}>0.05 \\
p_{1-3}>0.05 \\
p_{2-3}>0.05\end{array}$ \\
\hline & Total group & 27 & 46 & 13 & \\
\hline
\end{tabular}

Note: ${ }^{1}$ — this microbiota type was suggested due to the specifics of the Androflor test (Enterobacteriaceae spp. / Enterococcus spp. are detected in a tube separately from other Gram-positive and Gram-negative facultative anaerobes without species identification); ${ }^{2}$ — this variant was applied when a proportion of several detected groups of microorganisms slightly differed from each other; ${ }^{3}$ — Fisher's test enabled calculation of significance of the differences. 
Several patterns were revealed while analysing the data. The higher semen TBL corresponded with the increased proportion of microbiota type IV (with predominance of obligate anaerobes) and lower detection rate of microbiota type III (with predominance of Enterobacteriaceae spp./ Enterococcus spp. group). We have also noted the increased detection rate of microbiota type $\mathrm{V}$ (with predominance of transient microbiota, Lactobacillus spp.); this can be the result of the patients not abstaining from intercourse for $3-5$ days before the semen collection. Low TBL in semen samples often corresponded with microbiota type III and VI (mixed microbial community, no dominating group). As the TBL increased the microbiota composition changed.

Microbiota type I (with predominance of Gram-positive facultative anaerobes) was detected by RT PCR in $17.4 \%$ of samples only, while semen culture determined this variant in $50 \%$ cases.

\section{Comparison of the RT PCR and culture-based technique results}

RT PCR in $100 \%$ of cases confirmed culture findings. However, in all culture-positive semen samples additional microorganisms were identified by molecular technique, mostly of the nonculturable or difficult to culture species. It should be noted specifically that RT PCR revealed obligate anaerobes, which cannot grow in vitro, in all samples.

According to the RT PCR results, microorganisms were found in all culture-negative samples. Microbiota type III (with predominance of Enterobacteriaceae spp. / Enterococcus spp. group) was determined in 5 (35.7\%) samples out of 14; microbiota type I (with predominance of Gram-positive facultative anaerobes) - in $4(28.5 \%)$ samples out of 14 ; microbiota type IV (with predominance of obligate anaerobes) in 2 (14.3\%) samples; microbiota type II, V and VI — in 1 sample each (7.2\%). In all these samples the TBL was less than $10^{4} \mathrm{GE} / \mathrm{ml}$, which may partly explain why the cultures were negative.

Next, we analyzed the concordance of the determined predominant group of bacteria by culture method and by RT PCR (Table 2).
The culture results matched those of RT PCR in 21 (24.4\%) of 86 cases. In these samples, the only isolated species or the quantitatively predominant species detected by culture method belonged to the same predominant group as detected by the RT PCR. In other cases, either culture was negative (14 (16.8\%)) or RT PCR determined other groups of bacteria as predominant.

The TBL detected by RT PCR corresponded to colony count in culture technique in $41(47.7 \%)$ of 86 samples; in $38(44 \%)$ cases, there were 10 to 1000 -fold difference. In 7 (8.3\%) samples, the number of microorganisms identified by RT PCR was less than colony count by the culture technique. The discordant result occurred when the following species were cultured: S. agalactiae (2 samples), S. anginosus (2 samples), S. mitis / S. oralis, S. hominis, L. crispatus (1 sample each). The in vitro growth properties of bacteria can vary significantly, and some species could not stand even short-term transportation.

\section{DISCUSSION}

Using culture technique, the clinically insignificant amounts of normal microbiota microorganisms, mainly Gram-positive facultative anaerobes, were detected in most semen samples. Their colony count was less than $10^{4} \mathrm{CFU} / \mathrm{ml}$ in $43 \%$ of samples [10]. A number of commensal species cultured in the sample may indicate specimen contamination.

RT PCR in $100 \%$ of cases confirmed the results of semen cultures. The growth of a pure culture of a given microorganism corresponded to the positive signal in the relevant Androflor group, including all the 14 culture-negative samples. The lack of in vitro growth of most microorganism groups detected by RT PCR is quite understandable: most of them are either difficult to culture or non-culturable [11].

RT PCR and culture results mainly differed in determination of the predominant microbial group. The two methods gave identical results in $24.4 \%$ of cases. There are two possible reasons behind discordant results. Firstly, the bacteria have different in vitro growth properties, and secondly, some species may have not survived transportation. In addition, obligate anaerobic microorganisms cannot be detected using culture

Table 2. Comparison of the predominant groups of microorganisms according to culture-based technique and RT PCR results $(n=86)$

\begin{tabular}{|c|c|c|c|c|c|c|c|}
\hline \multirow[b]{2}{*}{$\begin{array}{l}\text { Predominant group } \\
\text { of bacteria according } \\
\text { to RT PCR }\end{array}$} & \multicolumn{7}{|c|}{ Predominant group of bacteria according to culture-based technique } \\
\hline & $\begin{array}{c}\text { Gram-positive } \\
\text { facultative anaerobes } \\
(n=15)\end{array}$ & $\begin{array}{c}\text { Gram-positive } \\
\text { facultative anaerobes } \\
(n=4)\end{array}$ & $\begin{array}{l}\text { Enterobacteriaceae spp./ } \\
\text { Enterococcus spp. group } \\
\qquad(n=23)\end{array}$ & $\begin{array}{l}\text { Obligate } \\
\text { anaerobes } \\
(n=27)\end{array}$ & $\begin{array}{l}\text { Transient } \\
\text { microflora } \\
(n=7)\end{array}$ & $\begin{array}{c}\text { Mixed } \\
\text { microflora } \\
(n=10)\end{array}$ & $\begin{array}{c}\text { No } \\
\text { microflora }\end{array}$ \\
\hline $\begin{array}{l}\text { Gram-positive } \\
\text { facultative anaerobes } \\
(n=15)\end{array}$ & 8 & 0 & 2 & 0 & 0 & 1 & 4 \\
\hline $\begin{array}{l}\text { Gram-negative } \\
\text { facultative anaerobes } \\
(n=4)\end{array}$ & 0 & 0 & 0 & 0 & 0 & 1 & 2 \\
\hline $\begin{array}{l}\text { Enterobacteriaceae } \\
\text { spp./ Enterococcus } \\
\text { spp. group }(n=23)\end{array}$ & 9 & 0 & 8 & 0 & 0 & 3 & 3 \\
\hline $\begin{array}{l}\text { Obligate } \\
\text { anaerobes }(n=27)\end{array}$ & 11 & 1 & 4 & 4 & 1 & 4 & 2 \\
\hline $\begin{array}{l}\text { Transient } \\
\text { microflora }(n=7)\end{array}$ & 5 & 0 & 0 & 0 & 1 & 0 & 1 \\
\hline $\begin{array}{l}\text { Mixed } \\
\text { microflora }(n=10)\end{array}$ & 7 & 0 & 2 & 0 & 0 & 0 & 1 \\
\hline No microflora & 0 & 0 & 0 & 0 & 0 & 0 & 0 \\
\hline
\end{tabular}


technique, which distorts the view of the semen microbiota's composition in general.

Culture technique and RT PCR determined the TBL per $1 \mathrm{ml}$ differently in $52.3 \%$ of cases. In $44 \%$ of samples, the TBL determined using RT PCR exceeded that identified by the culture technique 10 to 1000 -fold. In 7 (8.3\%) cases, the situation was quite the opposite: culture technique identified higher total bacterial load than RT PCR. It should be noted here that we understand the flaws of direct comparison of microorganism amounts detected by RT PCR and culture technique. Semen's viscosity and uniformity are heterogeneous, thus, bacterial cells can be distributed unevenly throughout the examined sample. Moreover, prior to subjecting a sample to RT PCR testing, we treated it with a mucolytic medium, which reduced its viscosity and, probably, made the distribution of microorganisms in the sample more even.

The data obtained as a result of this research allow recommending RT PCR (Androflor test) as an alternative to the culture technique in the comprehensive examination of the semen microbiota.

\section{CONCLUSIONS}

The advantages of RT PCR (Androflor test) for semen microbiota assessment were evaluated compared to culture method. Culture technique failed to reveal the majority of microorganisms in the samples; moreover, every sixth sample was considered culture negative. Using RT PCR, $8-15$ bacterial groups in the amounts of $10^{2}-10^{6} \mathrm{GE} / \mathrm{ml}$ were identified in all samples. RT PCR established the predominant group of bacteria in most samples. Additional species other than those detected by the culture technique were registered in all 86 samples. As for the predominant bacterial groups, the culture results corresponded those of RT PCR in only $24.4 \%$ of cases; the discrepancies were mainly associated with the culture technique's inability to detect difficult to culture or nonculturable bacteria, whereas Androflor allows detecting such. The etiological significance of identifying certain predominant groups of microorganisms and their amounts requires further research that take into account the clinical data and the patient's diagnosis.

\section{References}

1. Cornelia Gottschick, Zhi-Luo Deng, Marius Vital et al. The urinary microbiota of men and women and its changes in women during bacterial vaginosis and antibiotic treatment. Microbiome. 2017; 5 (99): 1-15.

2. Hou D, Zhou X, Zhong $X$, et al. Microbiota of the seminal fluid from healthy and infertile men. FertilSteril. 2013 Nov; 100(5): 1261-9.

3. Nelson DE, Dong Q, Van der Pol B, et al. Bacterial communities of the coronal sulcus and distal urethra of adolescent males. PLoS One. 2012; 7 (5): e36298.

4. Weng SL, Chiu CM, Lin FM, et al. Bacterial communities in semen from men of infertile couples: metagenomic sequencing reveals relationships of seminal microbiota to semen quality. PLoS One. 2014 Oct 23; 9 (10): e110152.

5. Domes T, Lo KC, Grober ED, et al. The incidence and effect of bacteriospermia and elevated seminal leukocytes on semen parameters. Fertil Steril. 2012 May; 97 (5): 1050-5.

6. Mändar R, Punab M, Korrovits P, et al. Seminal microbiome in men with and without prostatitis. Int J Urol. 2017 Mar; 24 (3) 211-6.

\section{Литература}

1. Cornelia Gottschick, Zhi-Luo Deng, Marius Vital et al. The urinary microbiota of men and women and its changes in women during bacterial vaginosis and antibiotic treatment. Microbiome. 2017; 5 (99): 1-15

2. Hou D, Zhou X, Zhong $X$, et al. Microbiota of the seminal fluid from healthy and infertile men. FertilSteril. 2013 Nov; 100(5): 1261-9.

3. Nelson DE, Dong Q, Van der Pol B, et al. Bacterial communities of the coronal sulcus and distal urethra of adolescent males. PLoS One. 2012; 7 (5): e36298.

4. Weng SL, Chiu CM, Lin FM, et al. Bacterial communities in semen from men of infertile couples: metagenomic sequencing reveals relationships of seminal microbiota to semen quality. PLoS One. 2014 Oct 23; 9 (10): e110152.

5. Domes T, Lo KC, Grober ED, et al. The incidence and effect of bacteriospermia and elevated seminal leukocytes on semen parameters. Fertil Steril. 2012 May; 97 (5): 1050-5.

6. Mändar R, Punab M, Korrovits P, et al. Seminal microbiome in men with and without prostatitis. Int J Urol. 2017 Mar; 24 (3): 211-6.
7. Schuppe H-C, Pilatz A, Hossain H, et al. Urogenital Infection as a Risk Factor for Male Infertility. Deutsches Aerzteblatt Online. 2017. DOI: 10.3238/arztebl.2017.0339.

8. Bozhedomov V. A. Hronicheskij prostatit: novaja paradigma lechenija. Urologija. 2016; (36): 78-90. Russian.

9. Instrukcija po primeneniju nabora reagentov dlja issledovanija mikroflory urogenital'nogo trakta muzhchin metodom PCR v rezhime real'nogo vremeni Androflor ${ }^{\circledast}$ Skrin (OOO NPO «DNKTehnologija»). Dostupno po ssylke: http:www.dna-technology.ru/ information/aboutamethod/. Russian.

10. Jungwirth A, Diemer T, Kopa Z, et al. EAU Guidelines on Male Infertility. 2017. Available from: https://www.researchgate.net/ publication/318239925_EAU_Guidelines_on_Male_Infertility_2017.

11. Aragón IM, Herrera-Imbroda B, Queipo-Ortuño MI, et al. The Urinary Tract Microbiome in Health and Disease. Eur Urol Focus. 2018 Jan; 4 (1): 128-38.

7. Schuppe $\mathrm{H}-\mathrm{C}$, Pilatz A, Hossain $\mathrm{H}$, et al. Urogenital Infection as a Risk Factor for Male Infertility. Deutsches Aerzteblatt Online. 2017. DOI: 10.3238/arztebl.2017.0339.

8. Божедомов В. А. Хронический простатит: новая парадигма лечения. Урология. 2016; (36): 78-90.

9. Инструкция по применению набора реагентов для исследования микрофрлоры урогенитального тракта мужчин методом ПЦР в режиме реального времени Андрослор ${ }^{\circledR}$ Скрин (ООО НПО «ДНК-Технология»). Доступно по ссылке: http:www.dna-technology.ru/information/aboutamethod/.

10. Jungwirth A, Diemer T, Kopa Z, et al. EAU Guidelines on Male Infertility. 2017. Available from: https://www.researchgate.net/ publication/318239925_EAU_Guidelines_on_Male_Infertility_2017.

11. Aragón IM, Herrera-Imbroda B, Queipo-Ortuño MI, et al. The Urinary Tract Microbiome in Health and Disease. Eur Urol Focus. 2018 Jan; 4 (1): 128-38. 